\title{
V8 Método alternativo por espectrometria de infravermelho próximo para determinação da umidade residual na vacina tríplice viral liofilizada
}

Melissa Chamon Alves Premazzi ${ }^{1}$, Eduardo da Silva Gomes de Castro ${ }^{1}$ 2, Annibal Duarte Pereira Netto ${ }^{3}$

${ }^{1}$ Bio-Manguinhos, Fiocruz, RJ

2 Universidade Federal Fluminense - UFF

3 Universidade Federal Fluminense - UFF

Introdução: $O$ estudo foi realizado na Vacina Combinada contra Sarampo, Caxumba e Rubéola, conhecida como Tríplice Viral - VVA. Vacinas deste tipo possuem umidade residual-UR entre $1 \%$ e $5 \%$ da massa do liófilo. Para a sua formação, são usados excipientes, em geral açúcares. A presença dos excipientes influenciará os níveis de UR, na qualidade do liófilo formada e, consequentemente, na estabilidade do produto. O método de determinação de UR frequentemente indicado pelas farmacopeias é o de Karl Fischer - KF. É um método de determinação primário, porém destrutivo, que sofre influência das condições ambientais, do manuseio da amostra, necessita de constante limpeza do eletrodo e troca da solução receptora e apresenta longo tempo de análise. O método proposto é a espectrometria por infravermelho próximo - NIR. O seu princípio é a conversão da radiação eletromagnética absorvida por uma molécula em energia vibracional. É um método rápido, não destrutivo e que não sofre influência do manuseio da amostra. A inexistência de material de referência de UR para estas formulações gera a necessidade de se utilizar um método auxiliar de determinação de umidade e a quimiometria para tratamento dos dados.

Objetivo: Desenvolver um método para determinação de UR na VVA por espectroscopia de NIR, utilizando o método de KF como técnica auxiliar.

Metodologia: Foram coletados espectros de cada frasco de vacina e posteriormente suas UR foram determinadas por KF. Foi construída uma curva utilizando um método de calibração multivariada através da relação entre as bandas de absorção de água e as UR obtidas na determinação por KF. Foram determinadas as UR em 20 frascos de vacina através desta curva e seus valores foram comparados aos obtidos pela técnica auxiliar.

Resultados: Através de comparação entre os resultados de UR determinados por ambos os métodos, observamos que a maior discrepância foi de $-0,05 \%$, com valores de UR iguais a $1,82 \%$ pelo método de KF e 1,77\% por NIR. O método proposto ainda apresentou menor desvio padrão, 0,068 contra 0,24 pelo método de KF e amplitude 
de 0,25 contra 0,52 por KF. A curva de calibração utilizada apresentou coeficiente de correlação igual a 0,9982 e RMSEC de 0.0161 .

Conclusão: O método de espectroscopia por NIR é aplicável à determinação da UR de VVA e vantajoso pela redução da exposição dos analistas ao reagente de KF, do volume de resíduos químicos, da quantidade de amostras e do tempo de análise. Este último sofre uma redução considerável de 120 minutos por Karl Fischer contra apenas 5 minutos por NIR, por lote de vacina analisado. As próximas etapas do trabalho serão a determinação da influência dos excipientes nas bandas de absorção por NIR, da cinética de absorção de umidade nas condições de estocagem, da validade da curva de calibração e a validação do método.

Palavras-Chave: Umidade Residual, Vacina, NIR 